\title{
De-mythifying the Ramayana: A Study of the 'Devoiced' Surpanakha
}

\author{
Aditi Dirghangi* and Seemita Mohanty \\ National Institute of Technology Rourkela, India
}

\begin{abstract}
The famous Indian epic Ramayana composed by poet Valmiki between the $4^{\text {th }}$ and $5^{\text {th }}$ century $\mathrm{BC}$ is a potent corpus of mythology that has affected the creative imagination of writers from all walks of life. Down the ages it has undergone numerous re-interpretations and retellings. With its grandiose narrative, it also conveys an inherent ideology that is sometimes irrefutable because of the 'inviolate' position it holds. To oppose these authoritative and discriminatory ideologies contemporary writers have re-narrated it with suitable mythic structures and have de-mythified the mythology according to the sensibilities of time. The hierarchical dominance of the privileged characters, and the ideology of the patriarchy are countered and the unheeded voices of the 'minor' characters are offered spaces to narrate their stories. This paper seeks to examine the character of Surpanakha, Ravan's sister who is commonly perceived as ugly and brutal. She had transgressed the gender boundary, and was 'justifiably' mutilated for expressing her sexual desire towards Ram. Surpanakha embodies the label of the 'bad' woman of Indian mythology who in contrast to the character of Sita, a dutiful wife who easily succumbs to subjugation, is bold and liberated. This paper analyses Kavita Kane's Lanka's Princess (2017) and studies how the text gives space to Surpanakha by subverting India's most popular tale of morality. She narrates her story, expressing the progressive outlook of a 'new woman' who wants to assert her individuality and is constantly punished by the societal norms for her perceived transgressions.
\end{abstract}

Keywords: Re-interpretation, Devoiced, De-mythify, Patriarchy, New woman

\section{Introduction}

Down the decades, the epic Ramayana has been interpreted as the touchstone for morality in the Hindu culture. It holds a unique position in the lives of Hindus and serves as an appropriate model for ideal behaviour and virtue. The epic is a eulogy to the quintessence character of Lord Rama and his heroic deeds. He is called the uttampurush (ideal man) as he is the epitome of ethical conduct and an embodiment of dharma ${ }^{l}$. His image is worshipped and his actions are admired. The epic, though considered as a benchmark of morality and ethics, has instances and episodes, which contradict the image of Rama as the righteous one. Kathleen M. Erndl (1997) writes that many interpreters, commentators and authors of the Ramayana have found faults in the behaviour of Rama and have questioned few of his actions that are considered convincingly ethical. Few examples are - the episode of Rama's killing of the monkey king Vali unethically from behind his back, the banishment of Sita on the grounds of public censure, or the mutilation of Ravana's sister Surpanakha by Lakshmana at the command of Rama, after her confessions of love, and sexual overtures towards Rama. This article is an attempt to articulate the voice of Surpanakha who has been traditionally, though unfairly, portrayed as a monster, an adulteress, and wicked and flawed. Even though the Surpanakha episode from the Ramayana is considered integral to the main story, she is considered a marginal character in the whole epic. Her characterisation is done in sharp contrast to Sita's character,

\footnotetext{
${ }^{1}$ Dharma is a concept core to Hinduism and it believes in fulfilling one's duty according to the customs and laws. Lord Rama is considered the epitome of Dharma, a righteous king who abides by the law and this attribute makes him the ideal man to be admired.
} 
who is generally considered to be the epitome of feminine qualities and virtues. Surpanakha dared to express her sexuality transgressing the societal markers of conceived femininity. The character of Surpanakha has been condemned on the grounds of body, colour, choice and gender. On one hand Rama is shown as a chivalrous protector of women, yet on the other when he is seen commanding Lakshmana to mutilate Surpanakha for transgressing the gender boundaries, there are hardly any dissenting voice. On the contrary, there are efforts made to convince the act of mutilation as a punishment for a woman's dominion and sexuality when left unchecked by male control. There are also retellings that justify this mutilation on ethical grounds - a woman like Surpanakha who is shameless, brutal, impure and immodest, deserves such a punishment. The tale of the Ramayana upholds several ambiguous dichotomies between the good and the evil, the pure and the impure, and the male and the female. But with the publication of recent post-modern retellings these dichotomies have become blurred. The developments in the field of women studies have ideally questioned the ideologies and rules made by a patriarchal society. Most of the sacred texts are androcentric ${ }^{2}$ and offer inherent authoritative ideologies, with patriarchal discriminations devoicing the women characters and giving them minimal space to express their choices. The traditional gendered structures of Hindu society as represented in the epic are still valued and considered as the transcendental model for the youth in the contemporary times, but with post-globalisation retellings these models are being rationalised and subjected to women-centric consciousness.

Kavita Kane's Lankas's Princess (2017) is one such account of the unsung Surpanakha, Ravana's sister - a strong independent woman who is able to take decisions and make choices, but is questioned and controlled by the diktats of a patriarchal society. This novel narrates the plight of Surpanakha, from a young girl ridiculed and neglected for her looks, to her strong and independent choices in adult life refuting the stranglehold that her brothers had on her life, for which she is ultimately punished by a highly judgemental society that never forgives such transgressions. The novel is a gynocentric retelling of the Ramayana with Surpanakha as the protagonist narrating her neglected story.

\section{Surpanakha- The 'New-Woman'}

Though Kavita Kane's Lanka's Princess is set in the Treta Yuga ${ }^{3}$, the character of Surpanakha has more similarities with an accomplished and liberated $21^{\text {st }}$ century woman than any of her contemporaries. Here, Surpankha is not a submissive or a feeble character but a strong independent woman who never fails to express her choices, needs and emotions. Growing up surrounded by men, she was always neglected and supressed, but within the existence of this patriarchal dominance she rose to fight for her rights. She subverted the conventional societal construct of determining a woman biologically, which is the ideal feminine role of bearing children.

Surpanakha represents the attributes of the 'new woman,' similar to the established characters from the works of post-colonial writers like Anita Desai, Nayantara Sehgal, Shashi Deshpande, Manju Kapur, who have depicted women not as silent sufferers, but as spirited and determined individuals who know how to fight against injustice and humiliation. The female protagonists of these Indian writers had to face many vicissitudes of family-life but they keep abreast of all the hurdles that come their way in their arduous quest for their own identities in a highly patriarchal society. They fight for emancipation and empowerment. In Indian society, the term 'new woman'

\footnotetext{
${ }^{2}$ The Ramayana and its retellings were majorly written by men like; Valmiki's Ramayana $\left(4^{\text {th }}-5^{\text {th }}\right.$ C. BC.), Kamban's Iramvataram $\left(12^{\text {th }} \mathrm{C}\right.$.), Tulsidas's Ramcaritmanas $\left(16^{\text {th }} \mathrm{C}.\right)$, they were also androcentric in nature.

${ }^{3}$ In Hindu philosophy there are four ages of mankind and Treta Yuga is the second out of the four. It follows the Satya Yuga and is followed by the Dvapara Yuga and Kali Yuga. Treta means third and the name is indebted to the three incarnations of Vishnu were seen in this Yuga, the sixth and seventh incarnations of Parashuram and Rama respectively.
} 
signifies the awakening of women into a realisation of their appropriate place in the family and society. Conscious of individuality, the new Indian woman asserts her rights as having a status equal to that of a man in the society. They struggle to be independent, breaking the old shackles of submission and mute-sufferings. Anita Desai's protagonists also portray similar attributes of self-assertion within the existing patriarchal setup. Maya from Cry, The Peacock (1963), had an irresistible desire for self-assertion and emancipation to acquire autonomy in the patriarchal setup of her family. Monisha from Voices in the City (1965), was conscious of her identity and silently defied the traditional values to seek meaning in life. Sita from Where Shall We Go This Summer (1975), was entrapped within the confinement of patriarchal regulations, and to defy those, she takes recourse to a secluded life in the Manori Island. In this context, expressions like entrapment, madness, exile and isolation could be considered as distinctive themes exhibited by the protagonists in the above mentioned works and are relevant to the understanding of the concept of new woman. This works portrayed the inner psyche of women and their insecurities. And these women promptly voiced their inner self and asserted their identity within the patriarchal structures. Likewise, Kavita Kane's Surpanakha was also entrapped within the confinement of control by her brothers. The incessant disparity of gender that she faced in her family drove her to a frenzied level for vengeance and to defy all these discrimination she self-imposed an exile.

According to Kane, young Surpankha's personality was completely influenced by her complex relationship with her brothers and mother, and the open partiality shown by her mother towards her brothers. She was ridiculed by her siblings, and even by her mother for her ugly looks and dark complexion in comparison to their good looks and fair complexion. Nothing can be more humiliating and miserable for a young girl when her own mother taunts her for her looks and complexion. Additionally, she was the least favoured child, and always denied and ignored. Her decisions were considered inconsequential by her family members, but the strong-willed and assertive Surpanakha liberated herself from the shackles of the male-dominated society by claiming her rights and choices. She was physically strong which strengthened her individual capacity to self-defence. Additionally, her keen intelligence and will-power enabled her to take decisions of her life, primarily of her own marriage, much to the dejection of her family members. She never hesitated to express her bodily desires, continually resisted the judgements made on her persona, and always sought to assert her identity and individuality.

\section{Meenakshi: The Girl who Became Surpanakha}

Surpanakha was born to sage Vishravas and Asura princess Kaikesi, the youngest among four siblings, with brothers Ravana, Kumbhakarna and Vibhisan being elder to her. Her birth was a disappointment for Kaikesi as she needed more number of sons to fulfil her unaccomplished dream of regaining the lost kingdom of Lanka, which was once ruled by her father. Her father was forced to give up his throne to Lord Vishnu, and Vishnu placed Kuber, son of Rishi Vishvaras and great grandson of the creator of the universe, Brahma himself, as the new King. Kaikesi had cleverly plotted to marry the gullible Rishi Vishvaras, who madly fell for her and was completely ignorant of her true intents. Kaikeshi's father Sumali, and mother Taraka conspired the meeting and mating of their daughter and Rishi Vishvaras. Rishi was already married to Ilavida and was father to Kuber, and much to the consternation of everyone, left his family and married Kaikeshi. Kaikeshi had three sons and she needed more sons to rule the three worlds and the golden city of Lanka. Kaikeshi recollects, "That is why I married Vishvaras, so that I could beget the best progeny, the most powerful and most wise to win back what we have lost" (2). However, the birth of a girl drowned her in disappointment. Looking at her daughter, she could not control the sense of bitterness clouding her mind, she thought, "This girl-child has cheated me of my plans" (2). Her disappointment was so intense that she could not stop herself from scornfully commenting on her looks, "She hardly looks beautiful or like me. In fact she is quite ugly!"(2) The stage was set. Another girl, another individual, discriminated against, and pushed out on the journey of her life with a concocted handicap based on her looks and complexion. A new-born baby being so commented upon by her own mother can only expect humiliation and rejection in her life. She either accepts her humiliation, or fights the world tooth-and-nail. In Surpankaha's case, it was almost literal. She was born dark, and bonny with abnormally long nails, almost like claws, curved and 
sharp, but her eyes were huge and honeyed like two golden drops shining against her dark skin. Vishvaras had named her Meenakshi, one whose eyes were as golden and as graceful as a fish. However, as she grew up, she preferred to be identified by her moniker Surpankha, the one with razor-sharp nails.

Growing up among three elder brothers and being a girl-child, Surpanakha was always neglected. Ravana was her mother's favourite, and Vibhishan, was her father's favoured child. The only person who comforted her was Kumbhakarna, her middle brother. Ravana and Vibhishan were always submerged in their world of selfabsorption. Ravana trained himself to become a great warrior and to claim back the throne of Lanka, which once belonged to his grandfather Sumali, the erstwhile king of Lanka. In the quest to fulfil his mother's lost dream, he mastered the art of weaponry, and learnt the four Vedas and the six shastras. Ravana was also an expert in music and his passion for politics was natural, which according to Sumali was an Asura blood trait. Both Sumali and Kaikeshi adored Ravana and believed him to be the rightful Asura heir to claim the throne of Lanka. Vibhishan was his father's pride, as he was exceptionally good with the Vedas and the shastras. He was more like his father, a rishi, engrossed in acquiring knowledge and wisdom. Kaikesi and Vishvaras argued over each other's respective favourites, Ravan and Vibhishan, and in the process completely neglected to give any attention to the happiness of their youngest child, Surpanakha. One of the instances was when Surpanakha found her pet lamb Maya lying dead in a pool of blood, her neck twisted, and her pink tongue sticking out. She was grief-stricken at the sight and was shocked to know that Ravana had killed her pet. Ravana in fit of rage had killed Maya because she had chomped away all the medicinal plants that he had planted. Surpanakha was stupefied with distress, and tearyeyed accused her elder brother, who showed no moral culpability for the violence he had executed. As Ravana growled at her, "You should have trained your pet, Meenu...she ruined months of efforts and patience that dumb animal" (7), Surpanakha felt her grief slowly coiling into a fury of rage and resentment towards her brother. She sprang on Ravan unsuspectedly and dug her nails into the tender flesh of his neck, her clawing fingers tearing the skin and exposing the flesh. Ravana, bleeding profusely cried out in pain and fury, 'you ugly wretch...Surpanakha, that is what she is... a witch with long, sharp claws'. (8) Even her mother rebuked her for her audacity to attack her elder brother. She also condemned her for not behaving like a girl but indulging in fights, 'Surpankha that is the right name for you, you monster'. Hearing her mother blatantly supporting Ravana, and uttering those words, she was completely disillusioned, and she screeched out of anger and pain, "Yes I am a monster." She proclaimed with professed pleasure that if those nails could protect her then she had no problem in being called Surpanakha, the one with sharp nails.

Surpanakha seen from the eyes of her beautiful mother was nothing but an ugly looking child. She was frequently commented upon as a monster and an ugly-looking wretch. Her self-confidence was repeatedly crushed and she felt like an outsider in her family of good-lookers, perennially waiting for some miracle to happen to hide her ostensible deformity. It was only Taraka, her maternal grandmother who boosted her confidence with soothing words about her unique beauty, “...love that smooth dusky skin, love that petite, fragile figure of yours, those big honey drop eyes...' (22). Her able defence against outside forces was criticised by her mother; on one occasion when she fought aggressively in support of her meek brother Vibhishan, she was reprimanded by her mother that Vibishan was a boy and could take care of himself. Similarly, after her violent retaliation against Ravana for killing her beloved lamb Maya, her mother admonished her by saying that she dare not attack her elder brother. The name Surpanakha was hurled at her by a furious Ravan because of her claw-like nails, and this name became her forced identity that she had to live with for the rest of her life. Today the readers hardly know that her original name was Meenakshi. For readers across generations she is only Surpanakha, the reviled one.

\section{Surpankha's Fight for Love}

Surpanakha's life in Lanka was under constant surveillance because of her over-protective brothers. She was not allowed to go beyond the premises of the palace and she felt trapped inside the magnificent palace. The glamour and opulence of the palace never allured her; on the contrary, it seemed to confine her, and her decisions, choices and needs. Surpanakha gradually grew up to a full woman and had become very sensuous looking with her heavy 
breasts, petite waist and round buttocks. Her dusky colour, voluptuous figure and the pair of beautiful and golden eyes were admired by men in Lanka, but nobody dared to approach her, as the suitors were petrified to face the wrath of her brother Ravana. She was an unwanted child since her birth and had to suffer discrimination at every step. This disparity created a division between her and her family and due to which she tried to find love in the simple things of life, like her pet lamb Maya, which was very dear to her but was mercilessly killed by her own brother. Her grandmother Taraka was also very close to her. Taraka adored her, boosted her morally and was the only person to take her side and defend her, but she was also killed in a conflict. She craved for love, affection and adoration, but her wishes were ignored all the time. Even after attaining the marriageable age, Surpanakha's desire for a marital life was largely ignored by her brothers, and instead they themselves got married. She was envious of Mandodari (Ravana's wife), whose brothers looked after their sister's well-being before their own, unlike her brothers who got married themselves without ever considering about their sister. She longed and wished for such brothers who would put her needs before theirs. All her brothers got married into powerful families to build alliances with powerful kingdoms. Surpanakha was very cynical of this, as she believed that these marriages were purely out of self-interest and these arrangements of love were in guise of expanding the kingdom of Lanka. Ravana wanted all the family-ties to be done with influential families. But Surpanakha was in search for true love and companionship, with no hidden interests.

In one of brother's marriage ceremony, she met Vidyujiva and she found the love that she was craving for years. She was charmed by his courage to approach her directly and confess his love for her. She was amused by his words of love, which she never thought she could find, 'I love you because there is no reason. I just hopelessly, irrationally did!'(115). Vidyujiva on the other hand was a rival of Ravana, a Kalkeya king and Kalkeyas always had an eye for the throne of Lanka, and after Ravana came to know about the love-affair he secretly planned to kill Vidyujiva. All the members of the family were sceptical of her choice and were against her decision of marrying Vidyujiva. Vidyjiva because of his Kalkeya lineage was doubted upon, and his proclaimed feelings for Surpanakha were considered as a veil to cover his malicious scheme of snatching the kingdom of Lanka from Ravana. But here again Surpanakha was determined to fight for her right to choose a life-partner. She went against the will of her family and managed to convince Ravana on the grounds of disclosing his unethical actions to his wife Mandodari. Ravana agreed to Surpanakha's marriage under the condition that Vidyujiva had to stay in Lanka after the marriage and serve in his court. Vidyujiva gave in to the deal and married Supanakha, but the deal could not suffice the anxiety Surpanakha sensed for her husband's well-being. Though she is portrayed as a vamp in the original epic, Kavita Kane's Surpanakha had a human side, she was a passionate and dutiful wife, and was affectionate towards her sisters-in law. She was fond of her nephews and was a loving mother to her son. But what triggered the ugly side of Surpanakha was the treacherous death of her husband in the hands of Ravana, proclaiming Vidyujiva as a traitor. Her whole family were unapologetic about the murder and persuaded her to believe that she was too gullible to fall for Vidyujiva. This evoked misery and vengeance in her and she plotted to destroy her family who murdered her husband around whom her life revolved. She schemed to use Rama and Lakshmana as pawns to finish off her brother Ravana. Her anger was directed at a family, which destroyed her identity, questioned her choices, ignored her values, and killed the love of her life in the guise of the safety of Lanka. The grief of being widowed by her own brothers was all-consuming and she imposed an exile on her own self in the Dandaka forest, far away from Lanka.

\section{Expressing a Desire for Male Intimacy}

The wilderness of Dandaka forest gave Surpanakha a sense of freedom and she loved the ravaged wilderness. Unlike Lanka where there was hostility inside the resplendent palace, in Dandaka existed a natural discipline where plants, animals, humans and demons feared but respected each other. The forest was not one's possession but for everyone. The forest became her home and she preferred the moniker Surpanakha over Meenakshi. The miseries of life had taken away the compassion and love she had within herself. The death of her husband had 
made her heedless to any emotion and she only yearned for vengeance. She had become a savagely violent woman, reborn as Surpanakha.

She moved out of Lanka with her son Kumar, pledging to take revenge of her husband's murder, and contemplating that it would be Kumar who would take the revenge. Though spending years in Dandaka the scars of the death of Vidyujiva were still fresh within her, and her son Kumar vowed to avenge his father's murder. He trained himself to fight against Ravana, mastered all the celestial and occult weaponry, but he also yearned for the blessings of lord Shiva, just as Ravana had been previously blessed. He set out on his journey for selfmortification, but was mysteriously killed while performing it. Surpanakha was left all alone in her fight for revenge. She lost both her husband and her son, and an unusual loneliness engulfed her in Dandaka forest. She was distraught with misery and panic as she realised that because of her demented lust for revenge, she had lost her son. But she also blamed it on her fate and her family who made her walk through this excruciating trail.

One day while wandering alone in the forest, Surpanakha's eyes caught a glimpse of Rama and Lakshmana. She was mesmerized at the pleasurable sight, the striking-looking brothers tightening the strings of their bows, their strong muscles rippling under their tanned skins and she felt a surge of hot blood rush in. "She wanted them, badly, madly. She wondered what it would be like to have them and her body grew hot, moist and yielding at the thought. They must be skilled and intense lovers, but she would control them" (193). She wanted to seduce them and believed that they would be easy prey like most men, susceptible to her sexual allure. No doubt, she felt an emotion of shame for lusting after two young men at her age, but she also wanted to find solace in lust, and feverishly wanted men to fill in the lonely hours. She recalled her grandmothers words, "...there was no shame in desiring a man" (194). She wanted sexual intimacy with either of the two men to dissipate the loneliness she felt after Vidyujiva's death. She rushed forward to expose her ravaging lust for them and approached Rama but was declined as he was accompanied by Sita, and he directed her towards Lakshmana as he was available, and was free to accept her. But Lakshmana also rejected her citing the fact that even though he was travelling alone, he was married to Urmila, who was waiting for him in Ayodhya. Lakshmana again directed her back towards Rama suggesting that he was just a mere servant to his brother Rama and she deserved better, so she must convince Rama. Surpanakha realised that both the brothers were mocking her, “... were laughing at her, reeling her to and fro like a toy, like a mere means of amusement " (200). She stood in the middle and watched the two brothers, handsome and cruel, grinning and poking fun at her. In the rage of rejection and humiliation, she tried to attack Sita but was stopped by Lakshmana. Ram ordered Lakshmana to teach the 'unvirtuous' Surpanakha a lesson she will never forget. He instructed Lakshman to mutilate her, 'maim her' (202), a punishment which will be a reminder for her dishonourable crime. Surpanakha could not believe her ears - 'maim her!' She was appalled by the declaration of such barbarity; she was unable to understand whether the punishment was for transgressing the perceived moral boundaries and assaulting their chastity, or for trying to attack Sita. She wondered how someone so beautiful could be so cruel to someone just for exhibiting bodily needs. Lakshmana's sword slashed off her nose and ears, she felt a sharp pain and the gush of warm blood on her skin. The throbbing pain made her confused; she touched her face, which felt odd. She was stricken with frenzied horror when she realised that Lakshmana had mutilated her nose and ears. She ran fanatically in a fire of agony trying to cover her bloodied face of pain and shame. Surpanakha fled to her brother Ravana and convinced him to avenge for the heinous crime that the princes had committed. She narrated the dreadful scene to him, but at the same time did not forget to describe the extraordinary beauty of Sita. She was shrewd enough to realise that even if her plight did not move Ravana to avenge her, Sita's extraordinary beauty would certainly force him to take some action. Her words aroused a passionate desire in Ravana and to avenge her sister's dishonour he abducted Sita, and carried her to Lanka. Humiliated by Rama and Lakshmana, Surpanakha becomes the cause of the war of Ramayana between Rama and Ravana. 


\section{Conclusion}

Surpankaha is one of the most ignored and misunderstood characters of the Ramayana. Even though the space offered to Surpnakha in Valmiki's Ramayana was inconsequential, yet her character was certainly important because she was the precursor to the war of Lanka. Kavita Kane's Lanka's Princess successfully recounts the unheard voice of Surpanakha and portrays an image that resonates into one's psyche. It questions the authoritarian ideologies the epic had burdened her with where she was presented as an immodest, unvirtuous and obnoxious woman. This alternative retelling of Ramayana narrates the story of Surpanakha, where she is portrayed as a strong and independent woman who is able to fight for her own rights and take her own independent decisions. She was a victim in the hands of patriarchal dominance and a gender-biased society. But she liberated herself from the clutches of the traditional gendered structures of the Hindu society through her strong will-power and individualistic determination. She made choices of her own and succeeded in attaining those choices. She had to travel through an excruciating trail, facing discrimination because of her gender, looks and her astuteness. Her choices were never taken seriously, and she was enforced upon by her brothers to believe that she was too gullible to make any appropriate choice. The traditional gender roles have always portrayed women as dependent beings who need guidance and protection, initially by her father or brother and later by her husband and son. According the Manusmriti, (Sanskrit: "Laws of Manu" or "The Remembered Tradition of Manu"), the ancient Hindu text that is traditionally considered as an influential guide in determining the structure and function of the Hindu society, the status of women is limited to the household and for bearing children. It instructs women that their role in the society is to be a good wife by obeying and serving their husbands. But Surpanakha rejects these gender roles, transgresses the markers of femininity and asserts herself within the patriarchal boundary. She avenges the insults meted out to her, fights for her rights, makes her own choices, and protects herself from the gendering done by her family. To that extent a remarkable parallel can be drawn between her, a character from an ancient Hindu epic, and the 'new woman,' or the $21^{\text {st }}$ century empowered woman who knows how to claim her own rights, make her own choices, is not averse to explicitly express her sexual desires for the man of her choice, and is not bound by the traditional moralities of the society.

The episode of mutilation of Surpanakha sheds light on the Hindu attitude towards female sexuality in relationship to polarities like pure and impure, 'good woman' and 'bad woman'. Sita and Surpanakha exemplify two types of women: Sita is good, pure, chaste and subordinate, whereas Surpanakha is evil, impure, unvirtuous and insubordinate. The good woman is the one who is controlled, both mentally and physically by her husband and whose sexuality is limited to child-bearing and service to her husband. Sita is subordinate to her husband; she comes to the forest as a companion to her husband. She is protected and controlled in every step. On the other hand, Surpanakha the bad woman, does not succumb to these controls, she is unattached and free. She conveys her sexual desires without any shame or inhibitions. She does not hide her desires and hence is considered unvirtuous, since it is expected of women to have satiable sexual appetites. Surpanakha's status as an independent woman is denounced and is perceived as dangerous because she assaulted the moralities of Rama and Lakshmana. But the question that is to be raised here is, does she assault the moralities of the two men, or is it their own inherent sexual weaknesses that pushes them to punish her rather than get exposed in front of everybody.

The novel opens and ends with a scene of the Krishna reincarnation of Rama, accepting and comforting Kubja, the reincarnation of Surpanakha whom he had turned down in his previous birth. All the miseries that Surpankaha had suffered in her previous life, the disfigurement suffered at the hands of Lakshmana on the instruction of Rama, and the penance of her present life where she was born with a hunchback, and facing discrimination and mockery, are all erased with Krishna's touch. Krishna transforms her twisted body into a new one, beautiful and serene. When Kubja asked him for his identity, Krishna replies: 
"I am the one who turned you down once. I am the same man. Ram then, now Krishna...I have come for you Kubja, for the grave misdeed I committed in my last life, where you were Surpanakha in your previous birth. And I was Ram.” (xiii)

Kavita Kane's Surpanakha represents the 'new woman' of the $21^{\text {st }}$ the century who does not succumb to control and dominance. She is an independent woman who rightfully expresses her choices, voices hers desires, and asserts her identity within the patriarchal controls. Though considered a demoness, she had a human side that was neglected. She was a strong liberated woman, a passionate lover, a dutiful wife and an affectionate mother. Through Lanka's Princess, the character of Surpanakha is empowered, and given a voice to speak and react.

\section{References}

ERNDL, M. K., 1997, The Mutilation of Surpanakha. In: Many Rāmāyanas: the Diversity of a Narrative Tradition in South Asia edited by P. Richman (New Delhi: Oxford University Press).

HARLAN, L., and COURTRIGHT, and P. B., 1995, From the Margins of Hindu Marriage: Essays on Gender, Religion and Culture (New York: Oxford University Press).

KANE, K., 2017, Lanka’s Princess (New Delhi: Rupa).

MENON, N., 2012, Seeing like a Feminist (New Delhi: Penguin Random House)

PYKETT, L., 1992, The “Improper" Feminine: the Women's Sensation Novel and the New Woman Writing (London: Routledge, 1992), p.137.

SHARMA, K. S., 2011, Redefining Self: Women in Postcolonial Indian English Literature: An Indian Approach. In: Women in Postcolonial Indian English Literature: Redefining Self edited by M. Agarwal (New Delhi: Atlantic Publishers and Distributors).

THAPAN, M., 1998 Embodiment: Essays on Gender and Identity (New Delhi: Oxford University Press). 